\title{
Performance Evaluation of Battery Powered Reaper
}

\author{
D.P. Tanti*, K.B. Jhala and C.V. Jadav \\ Department of Farm Machinery and Power Engineering, College of Agricultural Engineering \\ and Technology, Junagadh Agricultural University, Junagadh, Gujarat, India \\ *Corresponding author
}

\begin{abstract}
A B S T R A C T

\begin{tabular}{|l|}
\hline Ke y w o r d s \\
Manually drawn \\
reaper, Battery \\
powered reaper, \\
Reaper
\end{tabular}

Harvesting of crop is one of the important agricultural operations. The availability and cost of labour during harvesting season is the serious problem. Timely harvesting of the crop is vital to achieve better quality and higher yield of the crop. To ensure efficient and timely harvesting operation manually drawn battery powered reaper was developed at CAET, JAU, Junagadh. Performance evaluation of developed machine was carried out at different forward speeds $(0.8-1.2 \mathrm{~km} / \mathrm{h}, 1.3-1.7 \mathrm{~km} / \mathrm{h}$ and $1.8-2.2 \mathrm{~km} / \mathrm{h})$ and different cutter bar speeds (200 rpm, $300 \mathrm{rpm}$ and $400 \mathrm{rpm}$ ). The maximum effective field capacity and field efficiency was found $0.074 \mathrm{ha} / \mathrm{h}$ and $90.77 \%$ respectively. The maximum cutting and conveying efficiency of the developed reaper was found $95.01 \%$ and $89.66 \%$ respectively.

\section{Introduction}

The crop cutting is important stage in agriculture field. Two types of crop cutting methods are prevailing in India. Currently Indian farmers use conventional method for crop cutting i.e. cutting crop manually using labour but this method is time consuming, so as to minimize the time required for cutting the crop and also to avoid the bending posture of the labour while cutting and health hazard related to long term working in bending posture, A thought has been given to design a device that cuts the crop with higher amount of ease and comfort. It will reduce the cost of crop cutting in field. This will also reduce the operational cost and raise the financial

condition of Indian farmers (Ghumadwar and Banker, 2016).

Wheat (Triticum aestivum L.) belongs to family Poaceae and is believed to be originated from the Middle-East region of Asia. It is a crop of temperate zone with cool winters and hot summers being very conducive for its growth. In India, wheat is one of the major rabi crops of north Indian plains as well as north-west Himalayas and is the backbone of food security of nation as evident from its contribution to nearly onethird of total food production. It is considered as the most important food grain crop due to its bread making quality. Among the food crops, wheat is one of the most abundant
\end{abstract}


source of energy and proteins for the world population and its increased production is essential for food security. Wheat grain is rich in carbohydrates in addition to protein and gluten. The nutritive value is fairly high as compared to other cereals. It contains 71.20 , $11.80, \quad 1.50, \quad 1.50, \quad 0.05$ and $0.32 \%$ carbohydrates, protein, fat, mineral matter, calcium and phosphorus, respectively (Swaminathan et al., 1981).

Manjunatha et al., (2008) carried out performance evaluation of vertical conveyor paddy reaper having $3.5 \mathrm{hp}$ engine and $1.2 \mathrm{~m}$ cutter bar width. The actual field capacity of the power reaper was $0.3 \mathrm{ha} / \mathrm{h}$ with a field efficiency of $73 \%$ at an average operating speed of $3.2 \mathrm{~km} / \mathrm{h}$. The cost of cultivation of paddy crop could be reduced through mechanization of harvesting operations.

Chavan et al., (2015) developed manually operated reaper. The Manual operated reaper was high labour saving equipment requiring only $20 \mathrm{man}-\mathrm{h} / \mathrm{ha}$. The field efficiency was satisfactory which more than $66 \%$. The cost of harvesting with this manual operated reaper was 1250.4 ₹ /ha which was much less as compared $2000 ₹ /$ ha for traditional method.

Prakash et al., (2015) studied on the performance evaluation of reaper binder in rice crop. They found the effective field capacity as $0.294 \mathrm{ha} / \mathrm{h}$ with field efficiency of $67 \%$ and fuel consumption was 5.27 1/ha. They also compare the harvesting cost of reaper with manual harvesting by sickle and found that harvesting cost reduced by $40.74 \%$ using reaper binder.

\section{Materials and Methods}

On the basis of the functional requirement a battery powered reaper was designed and developed to harvest wheat crop in the field. Reaper consisted of battery as a power source, cutting unit, conveying unit and machine transportation unit. The working principle of reaper is that the DC motor transmit power to the transmission system and then it transfers to the cutter bar and conveyer belt.

Worm gear was used for power transmission and eccentric wheel was used to convert rotary motion in to reciprocating motion to the cutter bar for cutting the crop. Conveyer belt with lugs were provided to put the crop in right side of the direction of motion. A provision is made to adjust the height of cut by providing wheels.

\section{Machine parameters}

Machine parameters such as effective working width, speed of operation, theoretical field capacity, effective field capacity, field efficiency, header loss and conveying efficiency were measured/calculated as follows:

\section{Width of cut}

The operating width of the machine was measured at 5 randomly selected places in the field. The machine was capable of cutting two rows at a time throughout. The distance between two rows was $22.5 \mathrm{~cm}$.

\section{Forward speed of operation}

Forward speed of operation was calculated by observing time taken to cover $20 \mathrm{~m}$ run of the machine. Forward speed was calculated by following formula.

Speed $(\mathrm{km} / \mathrm{h})=\frac{\text { Distance }(\mathrm{m})}{\text { Time taken to cover the distance }\left(\mathrm{s}^{\mathrm{N}}\right.} \times 3.6$

\section{Theoretical field capacity}

Theoretical field capacity of machine is the rate of field coverage that would be obtained if the machine was performing its function at 
$100 \%$ of the time at the rated speed and always covered $100 \%$ of its rated width (Kepner et al., 2005).

$\mathrm{TFC}(\mathrm{ha} / \mathrm{h})=\frac{\text { working width }(\mathrm{m}){ }^{*} \text { forward speed }(\mathrm{km} / \mathrm{h})}{10}$

\section{Effective field capacity}

The Effective field capacity is the actual rate of coverage by the machine, based upon the total field time. The machine was operated at a fixed speed in the field for a fixed time the area covered during was measured. Effective field capacity (ha/h) was determined using following formula (Kepner et al., 2005).

$\operatorname{EFC}(\mathrm{ha} / \mathrm{h})=\frac{\text { Actual area covered, ha }}{\text { Time required to cover field, } \mathrm{h}}$

\section{Field efficiency}

Field efficiency is the ratio of effective field capacity to the theoretical field capacity expressed as percentage. It was determined using following formula (Kepner et al., 2005).

FE, $\%=\frac{\text { Effective field capacity }}{\text { Theorotical field capacity }} \times 100$

\section{Cutter bar speed}

Speed of cutter bar was set with the help of digital tachometer. It was measured the speed in rpm (revolution per minute).

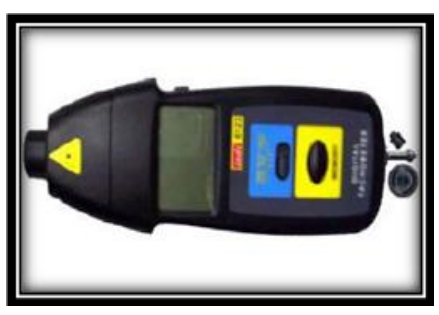

\section{Cutting efficiency}

Cutting efficiency of the reaper is determined as the ratio of total no of cut

Plant to the total no of plant present before cutting operation of the field.

Cutting efficiency $=\frac{\mathrm{W} 1-\mathrm{W} 2}{\mathrm{~W} 1}$

Where,

W1 $=$ No. of plants standing before cutting

$\mathrm{W} 2=$ No. of uncut plants after cutting

\section{Header loss}

The loss of the grains and ear heads left on the ground as a result of operation of cutter bar unit. These losses was determined based on samples taken from 5 different locations selected randomly and the data was converted in to $\mathrm{g} / \mathrm{m}^{2}$ and $\mathrm{kg} / \mathrm{ha}$ basis.

\section{Conveying efficiency}

Conveying efficiency of the reaper is calculated by the following formula.

Conveying efficiency $=\frac{\mathrm{W} 2}{\mathrm{~W} 1}$

Where,

$\mathrm{W} 1=$ No. of cut plants in 1mlength

$\mathrm{W} 2=$ No. of plants convey in $1 \mathrm{~m}$ length

\section{Results and Discussion}

The result of performance evaluation of battery operated reaper was obtained during the field tests. The results obtained have been analyzed and discussed under the following headings:

Field efficiency

Cutting efficiency

Header loss

Conveying efficiency

\section{Analysis of experimental data:}


The observations on different parameters were collected and analyzed using ANOVA technique.

\section{Field efficiency}

Effect of forward speed and cutter bar speed on field efficiency was analyzed using ANOVA technique. The effect of forward speed was observed highly significant on field efficiency at $1 \%$ level, whereas cutter bar speed has non-significant effect. The interaction of forward speed and cutter bar speed also showed non-significant effect on field efficiency.

\section{Effect of forward speed on field efficiency}

Comparison of mean values of field efficiency of all three forward speeds was statistically analyzed as shown in Table 1. The table clearly shows that the field efficiency was significantly affected by the forward speed with highest value in the speed range of $0.8-1.2 \mathrm{~km} / \mathrm{h}$ speed. It may be due to, as forward speed increases productive time of operation decreases and non-productive time remains same due to which field efficiency seems to be decreased.

Table.1 Mean values of field efficiency at different forward speed

\begin{tabular}{|lr|l|l|l|}
\hline $\begin{array}{l}\text { Forward } \\
\text { km/h }\end{array}$ & speed, & $\begin{array}{l}\mathbf{0 . 8}- \\
\mathbf{1 . 2}\end{array}$ & $\mathbf{1 . 3 -}$ & $\mathbf{1 . 8}-$ \\
\hline $\begin{array}{l}\text { Field } \\
\text { \% }\end{array}$ & efficiency, & $\mathbf{9 0 . 5 7}$ & $\mathbf{8 6 . 2 1}$ & $\mathbf{8 3 . 4 1}$ \\
\hline SEM 0.62 & $\mathrm{CD}_{05} 1.86$ & & & \\
\hline
\end{tabular}

\section{Effect of cutter bar speed on field efficiency}

The mean values of field efficiency at all the three levels of cutter bar speed were compared and given in Table 2. It reveals that cutter bar speed had non-significant effect on field efficiency. It also shows that on $200 \mathrm{rpm}$ of cutter bar speed, field efficiency was maximum.

Table.2 Mean values of field efficiency at different cutter bar speed

\begin{tabular}{|l|l|l|l|}
\hline $\begin{array}{l}\text { Cutter bar } \\
\text { speed }\end{array}$ & $\begin{array}{l}\text { 200 } \\
\text { rpm }\end{array}$ & $\begin{array}{l}\text { 300 } \\
\text { rpm }\end{array}$ & $\begin{array}{l}\text { 400 } \\
\text { rpm }\end{array}$ \\
\hline $\begin{array}{l}\text { Field } \\
\text { efficiency, \% }\end{array}$ & $\mathbf{8 7 . 0 2}$ & $\mathbf{8 6 . 6 8}$ & $\mathbf{8 6 . 4 9}$ \\
\hline \multicolumn{2}{|l|}{ SEMS } & & \\
\hline
\end{tabular}

\section{Combined effect of forward speed and cutter bar speed on field efficiency}

The mean values of the field efficiency at different forward speed and cutter bar speed are given in Table 3 . The interaction of forward speed and cutter bar speed shows non-significant at 5 percent level of significance. The highest field efficiency was found at combination of $0.8-1.2 \mathrm{~km} / \mathrm{h}$ forward speed and $200 \mathrm{rpm}$ cutter bar speed. Field efficiency at different cutter bar speeds for all three forward speeds are plotted in Figure 4.

Table.3 Mean values of field efficiency at different forward speeds and cutter bar speeds

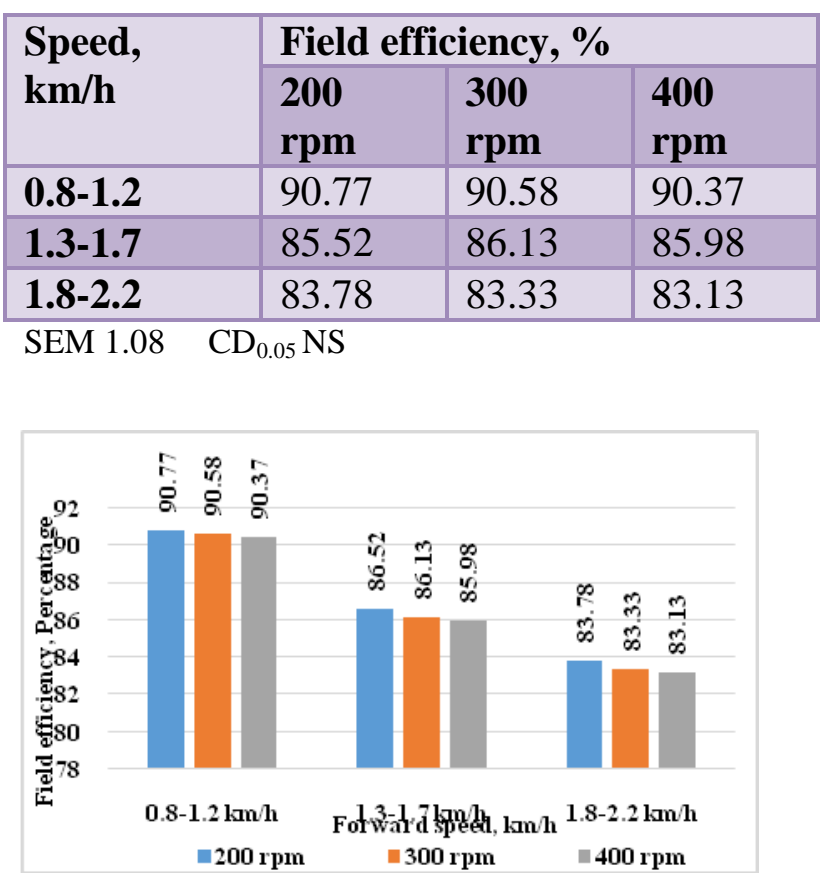

Fig.4 Effect of forward speed and cutter bar 
speed on field efficiency

\section{Cutting efficiency}

According to ANOVA technique forward speed and cutter bar speed both significantly affected on cutting efficiency, whereas the interaction of forward speed and cutter bar speed shows non-significant effect.

\section{Effect of forward speed on cutting} efficiency

The mean values of cutting efficiency at all three forward speeds were statistically analyzed, compared and given in Table 4. From the table it is clear that the mean values of cutting efficiency were significantly affected by forward speed and forward speed of $0.8-1.2 \mathrm{~km} / \mathrm{h}$ shows the highest cutting efficiency. Table shows that as forward speed increases from $0.8-1.2 \mathrm{~km} / \mathrm{h}$ to $1.8-2.2 \mathrm{~km} / \mathrm{h}$ cutting efficiency decreases. The reason seems to be the reduction in available time to harvest the crop.

Table.4 Mean values of cutting efficiency at different forward speed

\begin{tabular}{|lr|l|l|l|}
\hline $\begin{array}{l}\text { Forward } \\
\text { km/h }\end{array}$ & speed, & $\begin{array}{l}\mathbf{0 . 8}- \\
1.2\end{array}$ & $\begin{array}{l}\mathbf{1 . 3}- \\
\mathbf{1 . 7}\end{array}$ & $\begin{array}{l}\mathbf{1 . 8}- \\
\mathbf{2 . 2}\end{array}$ \\
\hline $\begin{array}{l}\text { Cutting } \\
\text { \% }\end{array}$ & efficiency, & $\mathbf{9 2 . 6 4}$ & $\mathbf{8 9 . 4 0}$ & $\mathbf{8 6 . 9 1}$ \\
\hline SEM $0.85 \quad \mathrm{CD}_{0.05} 2.53$ & & & \\
\hline
\end{tabular}

Effect of cutter bar speed on cutting efficiency

The mean values of cutting efficiency at all three cutter bar speeds are given in Table 5. It shows that cutter bar speed had significant effect on cutting efficiency.

Increase in cutter bar speed resulted in more no. of strokes in unit time which leads to more chances of stem being coming in front of cutter bar. This increases the cutting efficiency.

Table.5 Mean values of cutting efficiency at different cutter bar speed

\begin{tabular}{|l|l|l|l|}
\hline $\begin{array}{l}\text { Cutter bar } \\
\text { speed }\end{array}$ & $\begin{array}{l}\mathbf{2 0 0} \\
\text { rpm }\end{array}$ & $\begin{array}{l}\mathbf{3 0 0} \\
\text { rpm }\end{array}$ & $\begin{array}{l}\mathbf{4 0 0} \\
\text { rpm }\end{array}$ \\
\hline $\begin{array}{l}\text { Cutting } \\
\text { efficiency, \% }\end{array}$ & $\mathbf{8 7 . 5 6}$ & $\mathbf{8 9 . 4 5}$ & $\mathbf{9 1 . 9 4}$ \\
\hline \multicolumn{2}{|l|}{ SEM 0.85 $\mathrm{CD}_{0.05} 2.53$} & \\
\hline
\end{tabular}

Combined effect of forward speed and cutter bar speed on cutting efficiency

The mean values of the cutting efficiency at different forward speeds and cutter bar speeds are given in Table 6. The interaction of forward speed and cutter bar speed shows non-significant effect on cutting efficiency. The highest cutting efficiency was found at combination of $0.8-1.2 \mathrm{~km} / \mathrm{h}$ speed and 400 rpm cutter bar speed. Cutting efficiency at different cutter bar speed for all three forward speeds are plotted in Figure 5.

Table.6 Mean values of cutting efficiency at different forward speed and cutter bar speed

\begin{tabular}{|c|c|c|c|}
\hline \multirow[t]{2}{*}{$\begin{array}{l}\text { Speed, } \\
\text { km/h }\end{array}$} & \multicolumn{3}{|c|}{$\begin{array}{l}\text { Cutting } \\
\text { percentage }\end{array}$} \\
\hline & $\begin{array}{l}200 \\
\text { rpm }\end{array}$ & $\begin{array}{l}300 \\
\text { rpm }\end{array}$ & $\begin{array}{l}400 \\
\text { rpm }\end{array}$ \\
\hline 0.8-1.2 & 90.54 & 92.38 & 95.01 \\
\hline 1.3-1.7 & 87.30 & 89.25 & 91.67 \\
\hline 1.8-2.2 & 84.85 & 86.74 & 89.15 \\
\hline
\end{tabular}

SEM $1.47 \quad \mathrm{CD}_{0.05} \mathrm{NS}$

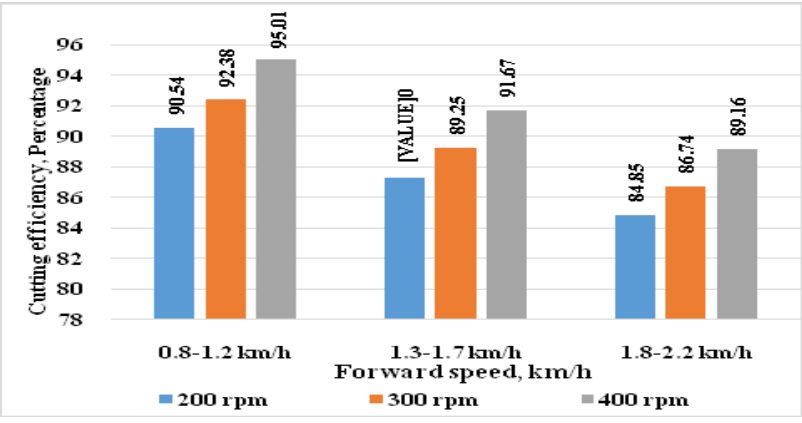

Fig.5 Effect of forward speed and cutter bar 
speed on cutting efficiency

\section{Header loss}

According to ANOVA technique header loss had significantly affected by forward and cutter bar speed both. The interaction of forward speed and cutter bar speed also shows significant effect.

\section{Effect of forward speed on header loss}

Mean values of header loss at all three forward speeds were statistically analyzed, and given in Table 7.

From the table it is clear that the header loss is highly significant by the forward speed and $0.8-1.2 \mathrm{~km} / \mathrm{h}$ of forward speed shows the minimum header loss. The reason seems to be that as forward speed increases the shattering of grains also increases and there for header loss may be increased.

Table.7 Mean values of header loss at different forward speed

\begin{tabular}{|c|c|c|c|}
\hline Forward speed, $\mathbf{k m} / \mathbf{h}$ & $\mathbf{0 . 8}-1.2$ & $\mathbf{1 . 3 - 1 . 7}$ & $\mathbf{1 . 8 - 2 . 2}$ \\
\hline Header loss, $\mathbf{g} / \mathbf{m}^{2}$ & 4.68 & $\mathbf{5 . 0 1}$ & $\mathbf{5 . 3 9}$ \\
\hline SEM $0.067 \quad \mathrm{CD}_{0.05} 0.199$ & & \\
\hline
\end{tabular}

\section{Effect of cutter bar speed on header loss}

The mean values of header loss at all three cutter bar speeds are compared and given in Table 8. As cutter bar speed increases the header loss also increases.

The mean values of header loss for all cutter bar speed were highly significant at 1 percent level. It also shows that on $400 \mathrm{rpm}$ of cutter bar speed, header loss was maximum. Here also it seems that as the cutter bar speed increases the shaking of stems is increased and due to this movement, shattering of grain results in higher header loss.
Table.8 Mean values of header loss at different cutter bar speed

\begin{tabular}{|ll|l|l|l|}
\hline $\begin{array}{l}\text { Cutter } \\
\text { speed }\end{array}$ & bar & $\begin{array}{l}\mathbf{2 0 0} \\
\text { rpm }\end{array}$ & $\begin{array}{l}\mathbf{3 0 0} \\
\text { rpm }\end{array}$ & $\begin{array}{l}\mathbf{4 0 0} \\
\text { rpm }\end{array}$ \\
$\begin{array}{ll}\text { Header } \\
\text { g/m }\end{array}$ & loss, & $\mathbf{4 . 2 7}$ & $\mathbf{5 . 0 0}$ & $\mathbf{5 . 8 1}$ \\
\hline SEM 0.067 & \multicolumn{2}{|c|}{$\mathrm{CD}_{0.05} 0.199$} & & \\
\hline
\end{tabular}

Combined effect of forward speed and cutter bar speed on header loss

The mean values of the header loss at different forward speeds and cutter bar speeds are given in Table 9. The interaction of forward speed and cutter bar speed shows significant effect on header loss. Both forward speed and the cutter speed has shown the increasing trend in the range of experimental data. Header loss at different cutter bar speed for all three forward speeds is plotted in Figure 6.

Table.9 Mean values of header loss at different forward speed and cutter bar speed

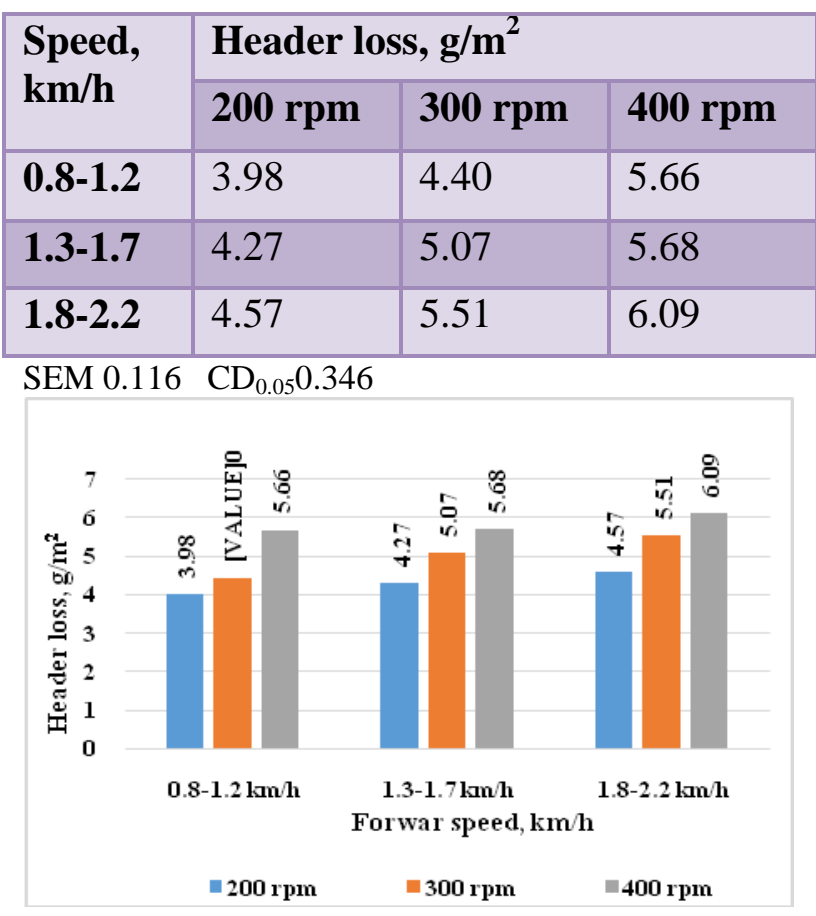

Fig.6 Effect of forward speed and cutter bar 
speed on header loss

Fig.1 Conceptual design of battery powered reaper

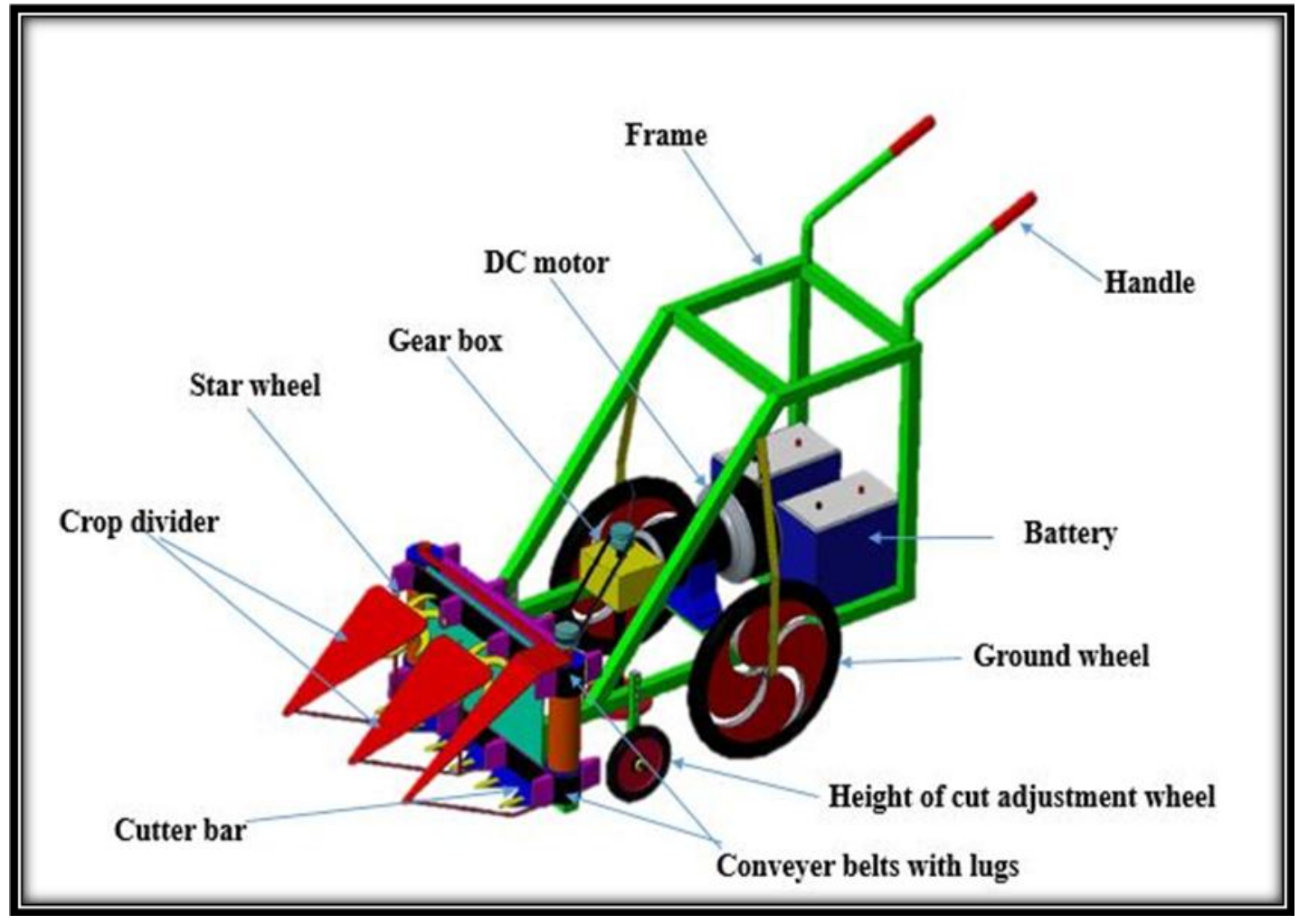

Fig.2 Developed battery powered reaper 


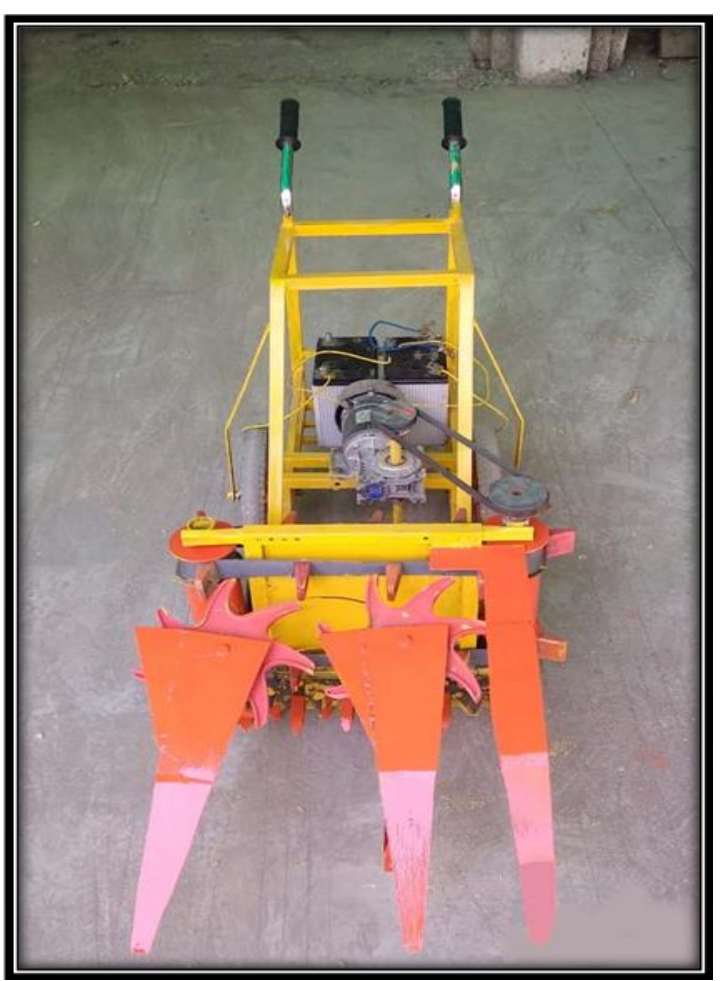

\section{Conveying efficiency}

Effect of forward speed and cutter bar speed on conveying efficiency was analyzed using ANOVA technique. The forward speed and cutter bar speed affected significantly on conveying efficiency. Where, as the interaction of forward speed and cutter bar speed shows non-significant effect.

\section{Effect of forward speed on conveying efficiency}

The mean values of conveying efficiency of all three forward speeds were statistically analyzed and given in Table 10. From the table it is clear that forward speed had highly significant effect on conveying efficiency. It is also observed that lower the forward speed higher is the conveying efficiency. It may be due to reduction in available time to handle the bulk material that has been cut by cutting unit. Higher forward speed causes more volume to be handled in short duration and there may mishandling.
Table.10 Mean values of conveying efficiency at different forward speed

\begin{tabular}{|l|l|l|l|}
\hline $\begin{array}{l}\text { Forward speed, } \\
\text { km/h }\end{array}$ & $\begin{array}{l}\text { 0.8- } \\
\mathbf{1 . 2}\end{array}$ & $\begin{array}{l}\text { 1.3- } \\
\mathbf{1 . 7}\end{array}$ & $\begin{array}{l}\mathbf{1 . 8}- \\
\mathbf{2 . 2}\end{array}$ \\
\hline $\begin{array}{l}\text { Conveying } \\
\text { efficiency, \% }\end{array}$ & $\mathbf{8 6 . 7 9}$ & $\mathbf{8 4 . 4 6}$ & $\mathbf{8 2 . 8 7}$ \\
\hline SEM 0.75 $\mathrm{CD}_{0.05} 2.23$ &
\end{tabular}

\section{Effect of cutter bar speed on conveying efficiency}

The mean values of conveying efficiency of three different level of cutter bar speed were compared as given Table 11. Cutter bar speed shows highly significant effect on conveying efficiency. It also shows that on $400 \mathrm{rpm}$ of cutter bar speed, conveying efficiency was highest. It is also observed that as the cutter bar speed increases conveying efficiency also increases with in the range of 200 to $400 \mathrm{rpm}$. With increase in cutter bar speed the conveying belt and star wheel moves faster and thereby time available for the plant to fall after being cut reduces by the time crop falls down the plant is conveyed to the required 
destination.

Table.11 Mean values of conveying efficiency at different cutter bar speed

\begin{tabular}{|l|l|l|l|}
\hline Cutter bar speed & $\begin{array}{l}200 \\
\text { rpm }\end{array}$ & $\begin{array}{l}\text { 300 } \\
\text { rpm }\end{array}$ & $\begin{array}{l}\text { 400 } \\
\text { rpm }\end{array}$ \\
\hline $\begin{array}{l}\text { Conveying } \\
\text { efficiency, \% }\end{array}$ & 82.41 & 84.67 & 87.04 \\
\hline
\end{tabular}

SEM $0.75 \quad \mathrm{CD}_{0.05} 2.23$

Combined effect of forward speed and cutter bar speed on conveying efficiency

The mean values of the conveying efficiency at different forward speeds and cutter bar speeds are given in Table 12. The interaction of forward speed and cutter bar speed shows non-significant effect on conveying efficiency. The highest conveying efficiency was found at $0.8-1.2 \mathrm{~km} / \mathrm{h}$ forward speed and 400 rpm cutter bar speed. Conveying efficiency at different cutter bar speeds for all three forward speeds are plotted in Fig 7. Forward speed has decreasing trend and cutter bar speed has increasing trend in the range of experimental data.

Table.12 Mean values of conveying efficiency at different forward speed and cutter bar speed

\begin{tabular}{|l|l|l|l|}
\hline \multirow{2}{*}{$\begin{array}{l}\text { Speed, } \\
\mathbf{k m} / \mathbf{h}\end{array}$} & \multicolumn{3}{|c|}{ Conveying efficiency, \% } \\
\cline { 2 - 4 } & $\begin{array}{l}\mathbf{2 0 0} \\
\text { rpm }\end{array}$ & $\begin{array}{l}\mathbf{3 0 0} \\
\text { rpm }\end{array}$ & $\begin{array}{l}\mathbf{4 0 0} \\
\text { rpm }\end{array}$ \\
\hline $\mathbf{0 . 8 - 1 . 2}$ & 84.34 & 86.38 & 89.66 \\
\hline $\mathbf{1 . 3 - 1 . 7}$ & 82.13 & 84.87 & 86.38 \\
\hline $\mathbf{1 . 8 - 2 . 2}$ & 80.76 & 82.75 & 85.09 \\
\hline SEM 1.30 & $\mathrm{CD}_{0.05} \mathrm{NS}$ &
\end{tabular}

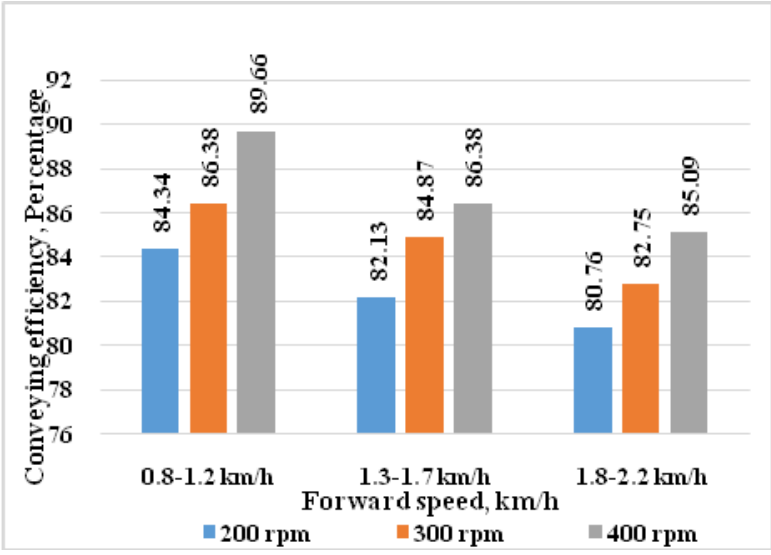

Fig.7 Effect of forward speed and cutter bar speed on conveying efficiency

Conclusions of the study are as follows:

1. Cutting and conveying efficiency increased with increase in cutter bar speed but decreased with increase in forward speed. The maximum cutting and conveying efficiency of the developed machine was found 95.01 $\%$ and $89.66 \%$ respectively at $0.8-1.2$ $\mathrm{km} / \mathrm{h}$ forward speed and $400 \mathrm{rpm}$ cutter bar speed.

2. The maximum field efficiency of the developed machine was found, 90.77 $\%$ at $0.8-1.2 \mathrm{~km} / \mathrm{h}$ speed and $200 \mathrm{rpm}$ cutter bar speed.

3. Header loss was increased with increasing forward speed and cutter bar speed. Minimum header loss was found at $0.8-1.2 \mathrm{~km} / \mathrm{h}$ forward speed and $200 \mathrm{rpm}$ cutter bar speed.

\section{References}

Chavan, P.B., Patil, D. K. and Dhondge, D. S. 2015. Design and development of manually operated reaper. IOSR Journal of Mechanical and Civil Engineering. 12(3):15-22.

Ghumadwar, R. A. and Bankar, V. H. 2016. Design and analysis of crop cutter. International Research Journal of Engineering and Technology (IRJET).3(7): 1095-1099. 
Kepner, R. A., Bainer, R. and Barger, E. L. 2005. Principles of Farm Machinery. Ch. 5. CBS Publishing Company, New Delhi, India.

Swaminathan, M. S., Kantha, J., Rao, N., Chandiramani, S. V., Subramanyam, L. and Indira, K. 1981. Balanced Diets and Nutritive Values of Common Recipes. $2^{\text {nd }}$ Edition, Sharda Press, Mangalore.

Prakash, R.J., Kumar, B.A., Reddy, G.A. and Reddy, K. V. S. 2015. Performance evaluation of reaper binder in rice crop. International Journal of Agricultural Engineering. 8(2): 232-238.

Manjunatha, M. V., Reddy, B. G. M., Shashidhar, S. D. and Joshi, V. R. 2008. Field performance evaluation of vertical conveyer paddy reaper. Karnataka Journal of Agricultural Sciences. 22(1): 140-142.

\section{How to cite this article:}

Tanti, D.P., K.B. Jhala and Jadav, C.V. 2019. Performance Evaluation of Battery Powered Reaper. Int.J.Curr.Microbiol.App.Sci. 8(07): 1998-2005.

doi: https://doi.org/10.20546/ijcmas.2019.807.238 